Article

\title{
Phytotoxicity and Chemical Characterization of Compost Derived from Pig Slurry Solid Fraction for Organic Pellet Production
}

\author{
Niccolò Pampuro ${ }^{1}$, Carlo Bisaglia ${ }^{2}$ (D), Elio Romano ${ }^{2}$, Massimo Brambilla ${ }^{2}$ (D), \\ Ester Foppa Pedretti ${ }^{3}$ and Eugenio Cavallo ${ }^{1, *}$ \\ 1 Institute for Agricultural and Earth Moving Machines (IMAMOTER), Italian National Research Council \\ (CNR), Strada delle Cacce, 73, 10135 Torino (TO), Italy; n.pampuro@ima.to.cnr.it \\ 2 Consiglio per la ricerca in agricoltura e l'analisi dell'economia agraria (CREA), \\ Centro di ricerca Ingegneria e Trasformazioni agroalimentari (CREA-IT), Sede di Treviglio, \\ Via Milano, 43, 24047 Treviglio (BG), Italy; carlo.bisaglia@crea.gov.it (C.B.); \\ elio.romano@crea.gov.it (E.R.); massimo.brambilla@crea.gov.it (M.B.) \\ 3 Dipartimento di Scienze Agrarie, Alimentari ed Ambientali, Università Politecnica delle Marche, \\ Via Brecce Bianche, 10, 60131 Ancona (AN), Italy; e.foppa@univpm.it \\ * Correspondence: eugenio.cavallo@cnr.it; Tel.: +39-011-3977-724
}

Received: 26 September 2017; Accepted: 31 October 2017; Published: 4 November 2017

\begin{abstract}
The phytotoxicity of four different composts obtained from pig slurry solid fraction composted by itself (SSFC) and mixed with sawdust (SC), woodchips (WCC) and wheat straw (WSC) was tested with bioassay methods. For each compost type, the effect of water extracts of compost on seed germination and primary root growth of cress (Lepidium Sativum L.) was investigated. Composts were also chemically analysed for total nitrogen, ammonium, electrical conductivity and heavy metal $(\mathrm{Cu}$ and $\mathrm{Zn})$. The chemicals were correlated to phytotoxicity indices. The mean values of the germination index (GI) obtained were 160.7, 187.9, 200.9 and 264.4 for WSC, WCC, SC and SSFC, respectively. Growth index (GrI) ranged from the $229.4 \%$, the highest value, for SSFC, followed by $201.9 \%$ for SC, and $193.1 \%$ for WCC, to the lowest value, $121.4 \%$, for WSC. Electrical conductivity showed a significant and negative correlation with relative seed germination at the $50 \%$ and $75 \%$ concentrations. A strong positive correlation was found for water-extractable $\mathrm{Cu}$ with relative root growth and germination index at the $10 \%$ concentration. Water-extractable $\mathrm{Zn}$ showed a significant positive correlation with relative root growth and GI at the $10 \%$ concentration. These results highlighted that the four composts could be used for organic pellet production and subsequently distributed as a soil amendment with positive effects on seed germination and plant growth (GI > 80\%).
\end{abstract}

Keywords: compost quality; cress bioassay; organic pellet; phytotoxicity; pig solid fraction

\section{Introduction}

In several European countries, intensive pig production systems produce high quantities of liquid manure (slurry) in limited and specific geographic areas. With reference to Italy, the 6th Italian National Census of Agriculture indicates that the regions of Piedmont, Lombardy and Emilia-Romagna account for $90 \%$ of all pig breeding in the country [1]. In both Europe and Italy, slurry storage and subsequent land application is the predominant manure management practice, likely due to its simplicity, low cost, and potential to reduce the total cost of crop production as a chemical fertiliser replacement [2]. However, this technique carries several environmental pollution risks, including an excessive input of potentially harmful trace metals [3], an increase in nutrient-nitrogen and phosphorous-loss from 
soils through leaching, erosion and runoff [4], and the emission of ammonia and greenhouse gases (GHG) [5]. In this context, the Nitrates Directive (91/676/EEC) introduced a limit of $170 \mathrm{~kg} \mathrm{ha}^{-1} \mathrm{y}^{-1}$ for application of animal manure nitrogen $(\mathrm{N})$ in areas of the member countries particularly exposed to water pollution, the so-called Nitrate Vulnerable Zones (NVZ). As a result of this restriction, and considering that the agricultural surface available for land spreading is limited, the slurry has to be transported to fields over greater distances, increasing the costs of the logistics. Consequently, there is a growing need for technologies to competitively manage livestock slurries. The separation of the solid and liquid fractions simplifies handling, making possible to adopt different management technique for the two phases. The liquid fraction (LF), which is rich in soluble N [6], is generally applied in areas adjacent to the farm, while the solid fraction $(\mathrm{SF})$, rich in nutrients $(\mathrm{P}$ and $\mathrm{N})$ and organic matter (OM) [6], and containing less water, can be applied to lands at greater distances. According to recent investigations, (unpublished data), the SF can be economically transported to fields up to $25 \mathrm{~km}$ from the livestock farm.

A promising approach for increasing the benefits of pig slurry SF, as well as for creating a potential new market for pig slurry-derived fertiliser, is to pelletise it. Pelletising increases the bulk density of SF from an initial value of $400-450 \mathrm{~kg} \mathrm{~m}^{-3}$ to a final one of more than $1000 \mathrm{~kg} \mathrm{~m}^{-3}[7,8]$. This allows better handling and transportation of SF at greater distances (even at hundreds of $\mathrm{km}$ as an order of magnitude) in order to move nitrogen (N) from Nitrate Vulnerable Zones to others less prone to pollution. Furthermore, Romano et al. [9] showed that pelletising homogenizes and further concentrates SF nutrients, thereby improving its fertilising and amending actions.

The moisture content of SF is the most important limiting factor for pelletising: a moisture content higher than $75-80 \%$ makes SF unsuitable for the process [10]. In previous studies [11,12], turning windrow composting has been proven as a simple and cheap technique to reduce the moisture content of SF. As a matter of fact, the heat generated by the composting process is able to reduce the moisture content of the substrate by $40 \%$, hence suitable for pelletizing.

Composting is an aerobic process that involves the decomposition of organic matter (OM) under controlled temperature, moisture, oxygen and nutrient conditions [13]. Composting also implies OM sanitization regarding weeds and pathogens [14].

For optimising the composting, a bulking agent is generally added to SF. This makes it possible to adjust substrate properties such as air space, moisture content, $\mathrm{C} / \mathrm{N}$ ratio, particle density, $\mathrm{pH}$ and mechanical structure, positively affecting the decomposition rate and, therefore, the development of the temperature [15]. Typical bulking agents used to compost N-rich wastes like animal manures are lignocellulosic agricultural and forestry by-products, such as cereal straw, cotton waste, and wood by-products [15]. Their low moisture and high $\mathrm{C} / \mathrm{N}$ ratios can improve the benefits of animal manures [13].

Compost derived from pig slurry solid fraction can be re-used as a new resource material, such as soil fertiliser and conditioner, to replace the more expensive and less environmentally sustainable chemical fertilisers for crop production [16,17]. However, the presence of non-biodegradable and toxic heavy metals limits agricultural application of composted manure [18]. Pig slurry SF often contains high concentrations of copper $(\mathrm{Cu})$ compared with other animal manures, because $\mathrm{Cu}$ supplements are normally added to pig rations to accelerate weight gain and increase the food conversion rates when fattening pigs [19]. In addition, zinc $(\mathrm{Zn})$ is also added to pig diets to counteract any toxicity which might be caused by the high $\mathrm{Cu}$ content [20]. Only a small proportion (5-10\%) of dietary $\mathrm{Cu}$ and $\mathrm{Zn}$ is absorbed by the pigs, while the rest is voided in the pigs faeces [20]. These elements, at high concentrations, can negatively affect seed germination, development of young seedlings, roots and plants growth.

In the present study, cress (Lepidium sativum L.) bioassays were used to evaluate the toxicity of four different composts derived from pig slurry solid fraction in order to examine if the organic pellet obtained by processing these composts can be recycled back to agricultural land without causing any negative effects on seed germination and plant growth. 


\section{Materials and Methods}

\subsection{Composting Trials}

Four different windrows were realised for composting; pig slurry solid fraction by itself (SSFC) and with the addition of 3 types of vegetal materials as bulking agents. The 3 mixtures subjected to the composting process were obtained by mixing, on wet basis, pig slurry solid fraction with $18 \%$ sawdust (SC), 30\% wood chips (WCC) and 14\% wheat straw (WSC), respectively. The materials were mixed in these percentages to obtain a theoretical $\mathrm{C} / \mathrm{N}$ ratio equal to 30 to optimise the composting process development [15]. In detail, the composting process took place by setting up four windrows as follows:

- SSFC: consisting of $6000 \mathrm{~kg}$ of pig slurry SF from screw press separator;

- SC: consisting of $5000 \mathrm{~kg}$ of pig slurry SF obtained from decanting centrifuge mixed with $900 \mathrm{~kg}$ of sawdust;

- WCC: consisting of $8000 \mathrm{~kg}$ of pig slurry SF from screw press separator mixed with $2400 \mathrm{~kg}$ of woodchips;

- WSC: consisting of $5000 \mathrm{~kg}$ of pig slurry SF from screw press separator mixed with $720 \mathrm{~kg}$ of wheat straw.

The windrows were placed on concrete floor under a covering, to avoid leaching and to protect from rain. The covering was not in contact with the surface of the windrow, allowing air to circulate and oxygen to be supplied. The ambient temperature and the temperatures inside the windrows at a depth of $0.4 \mathrm{~m}$ (T1), $0.8 \mathrm{~m}$ (T2) and $1.2 \mathrm{~m}$ (T3) from the surface of the windrows were continuously recorded (Figure 1) using thermocouple sensors (Type K) connected to a multichannel acquisition system (Grant, mod. SQ 1600, UK). To reduce the moisture content of the organic mixtures, making the materials suitable for pelletising, windrows were composted with a turning strategy: windrows were turned when the temperature of two of the three probes inside the composing material exceeded $60{ }^{\circ} \mathrm{C}$ [21]. The experimental composting process was observed for 130 days.
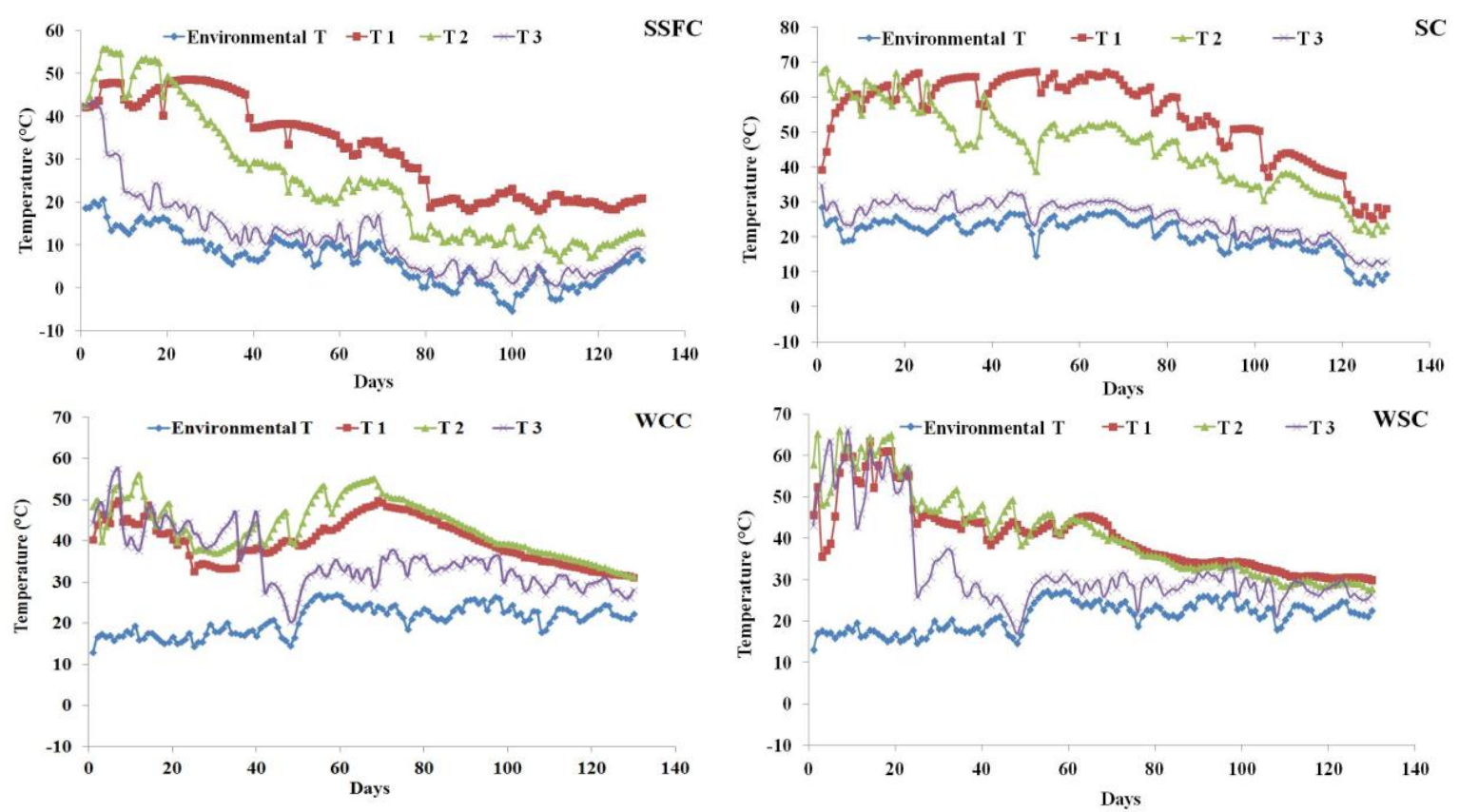

Figure 1. Average environmental temperature and temperatures development at a depth of $0.4 \mathrm{~m}$ (T1), $0.8 \mathrm{~m}$ (T2) and $1.2 \mathrm{~m}$ (T3) inside the SSFC, SC, WCC and WSC windrows. 
The trial was carried out at the IMAMOTER (Institute for Agricultural and Earth Moving Machines) testing site in Turin, Italy ( $44^{\circ} 57^{\prime} \mathrm{N}, 7^{\circ} 36^{\prime} \mathrm{E}, 245 \mathrm{~m}$ above sea level).

\subsection{Measuring Chemical Parameters}

At the end of the composting process, for each investigated windrow, a sample of about $200 \mathrm{~g}$ was collected from 5 random locations and thoroughly mixed to generate a single composite sample [18]. The obtained samples were stored for $24 \mathrm{~h}$ in a cooling cell at $0-7^{\circ} \mathrm{C}$.

Dry matter (DM) was calculated after drying at $105^{\circ} \mathrm{C}$ for $24 \mathrm{~h}$ (Table 1). Total nitrogen (TN) and ammonium $\left(\mathrm{NH}_{4}{ }^{+}\right)$were determined using the Kjeldahl standard method (BD40HT, Lachat Instruments). Water-extractable 1:10 $(w / v) \mathrm{Cu}$ and $\mathrm{Zn}$ were determined by atomic absorption spectrometry method (Elan 6000, Perkin-Elmer Corporation, Norwalk, CT, USA) [22]. (Table 1).

Table 1. Chemical characterisation of the four composts investigated (SSFC: slurry solid fraction compost, SC: sawdust compost, WCC: woodchip compost, WSC: wheat straw compost). Mean value of three replicates \pm Standard Deviation.

\begin{tabular}{|c|c|c|c|c|c|c|c|c|c|c|}
\hline \multirow{3}{*}{$\begin{array}{c}\text { Compost } \\
\text { Samples }\end{array}$} & \multicolumn{10}{|c|}{ Compost Characteristics ${ }^{a}$} \\
\hline & \multicolumn{2}{|c|}{ DM (\%) } & \multicolumn{2}{|c|}{$\mathrm{NH}_{4}^{+}\left(\mathrm{mg} \mathrm{g}^{-1}\right)$} & \multicolumn{2}{|c|}{ Total N (mg g $\left.{ }^{-1}\right)$} & \multicolumn{2}{|c|}{ Ext. $Z_{n}{ }^{b}\left(\mu g g^{-1}\right)$} & \multicolumn{2}{|c|}{ Ext. $C u^{b}\left(\mu g^{-1}\right)$} \\
\hline & 65.4 & \pm 0.15 & 2.9 & \pm 0.20 & 11.1 & \pm 0.19 & 24.0 & \pm 0.19 & 4.0 & \pm 0.12 \\
\hline SC & 68.1 & \pm 0.12 & 5.2 & \pm 0.15 & 25.5 & \pm 0.17 & 22.0 & \pm 0.15 & 3.2 & \pm 0.23 \\
\hline WCC & 67.9 & \pm 0.10 & 4.0 & \pm 0.28 & 17.3 & \pm 0.06 & 18.0 & \pm 0.06 & 1.9 & \pm 0.15 \\
\hline WSC & 67.5 & \pm 0.06 & 2.9 & \pm 0.16 & 14.6 & \pm 0.17 & 16.0 & \pm 0.17 & 2.8 & \pm 0.12 \\
\hline
\end{tabular}

${ }^{a}$ All characteristics are on dry weight basis; ${ }^{b}$ Ext: water extractable.

\subsection{Seed Germination Test}

The effect of compost phytotoxicity on seed germination, root length and germination index was determined with cress (Lepidium sativum L.) bioassays.

After determining the dry matter content of the four composts, the moisture content of the samples was standardised at $85 \%$ by adding deionised water [23]. The water extracts were obtained by making a $75 \%$ concentration of the standardised sample and shaking this for 2 hours. After shaking, the flasks were centrifuged at $6000 \mathrm{rpm}$ for $15 \mathrm{~min}$ and the supernatant was then again centrifuged for $15 \mathrm{~min}$. [23]. Not much is known about the phytotoxic level of compost derived from pig slurry SF; for this reason, four different concentrations, $75 \%, 50 \%, 25 \%$ and $10 \%$, of this supernatant were investigated. The $\mathrm{pH}$ and electrical conductivity (EC) of the extracts were determined (Table 2).

Table 2. Electrical Conductivity and $\mathrm{pH}$ of the four composts extracts (SSFC: slurry solid fraction compost, SC: sawdust compost, WCC: woodchips compost, WSC: wheat straw compost). Mean value of three replicates \pm Standard Deviation.

\begin{tabular}{ccccccccc}
\hline \multirow{2}{*}{$\begin{array}{c}\text { Compost } \\
\text { Samples }\end{array}$} & \multicolumn{9}{c}{$\mathbf{E C}\left(\mathbf{d S ~}^{-\mathbf{1}}\right)$} & \multicolumn{3}{c}{$\mathbf{p H}$} \\
\cline { 2 - 9 } & $\mathbf{7 5 \%}$ & $\mathbf{5 0} \%$ & $\mathbf{2 5 \%}$ & $\mathbf{1 0} \%$ & $\mathbf{7 5 \%}$ & $\mathbf{5 0} \%$ & $\mathbf{2 5 \%}$ & $\mathbf{1 0 \%}$ \\
\hline SSFC & $3.89 \pm 0.02$ & $2.83 \pm 0.06$ & $1.56 \pm 0.03$ & $0.75 \pm 0.02$ & $6.7 \pm 0.01$ & $6.5 \pm 0.03$ & $7.1 \pm 0.01$ & $6.4 \pm 0.02$ \\
SC & $7.96 \pm 0.16$ & $5.69 \pm 0.08$ & $1.97 \pm 0.02$ & $1.16 \pm 0.02$ & $7.4 \pm 0.03$ & $6.3 \pm 0.01$ & $6.3 \pm 0.02$ & $5.9 \pm 0.01$ \\
WCC & $1.69 \pm 0.17$ & $1.16 \pm 0.01$ & $0.61 \pm 0.01$ & $0.28 \pm 0.01$ & $5.5 \pm 0.01$ & $5.4 \pm 0.01$ & $5.7 \pm 0.02$ & $6.1 \pm 0.01$ \\
WSC & $1.90 \pm 0.06$ & $1.31 \pm 0.05$ & $0.69 \pm 0.01$ & $0.29 \pm 0.01$ & $6.6 \pm 0.02$ & $6.7 \pm 0.02$ & $7.2 \pm 0.01$ & $6.7 \pm 0.02$ \\
\hline
\end{tabular}

Ten cress seeds were placed on layer of filter paper (Schleicher and Schuell no. 595, $85 \mathrm{~mm}$ round filters) in $90 \mathrm{~mm}$ Petri dishes and $5 \mathrm{~mL}$ of each concentration was added [23]. Distilled water was used as control. The experiment had a completely randomised block design with three blocks and two pseudo-replications (i.e., two Petri dishes with the same dilution). The Petri dishes were incubated in a growth chamber at $27 \pm 2{ }^{\circ} \mathrm{C}$ and $70 \%$ relative humidity without photoperiod. At 24,48 and $72 \mathrm{~h}$ after 
the beginning of the incubation, percentage of germination was recorded. A visible root was used as the operational definition of seed germination. After $72 \mathrm{~h}$, also the length of the roots was measured.

The percentages of relative seed germination (RSG) after 24,48 and $72 \mathrm{~h}$, relative root growth (RRG) and germination index (GI) after $72 \mathrm{~h}$ of exposure to compost extracts were calculated as follows [24]:

RSG $(\%)=(n$ of seeds germinated in compost extract $/ \mathrm{n}$ of seeds germinated in control $) \times 100$

$\operatorname{RRG}(\%)=($ mean root length in compost extract $/$ mean root length in control $) \times 100$

$$
\mathrm{GI}(\%)=(\mathrm{RSG} \times \mathrm{RRG}) / 100
$$

\subsection{Plant Growth Bioassy}

The plant growth bioassay was carried out on Lepidium sativum L. using the 4 composts investigated (SSFC, SC, WCC and WSC) mixed with sand and peat.

The substrate was prepared by mixing sand and peat with volume ratio 1 to 1 [25]. The composts were added to the substrate in two doses equal to 75 and $150 \mathrm{~g}$ of dry matter (DM) for L of substrate [25].

The different mixtures obtained were placed in plastic pots of volume equal to $0.5 \mathrm{~L}$. On the bottom of the pots, a layer of expanded clay was placed to permit drainage. Initially, all pots were moistened with deionised water to attain a $60 \%$ water filled pore space (WFPS). The water added to each pot was calculated to supply $70 \%$ of the water holding capacity. Thereafter, soil water content was adjusted via a drop irrigation system every two to five days as required for the crop. All pots were kept in a greenhouse for 21 days at about $22^{\circ} \mathrm{C}$ [25].

The experiment had a completely randomised block design with six replicates for each of the substrates. A replicate of pots without compost was included into the study as control. .

The Growth Index (GrI) was calculated according to the following equation:

$$
\begin{gathered}
\operatorname{GrI}\left(75 \text { or } 150 \mathrm{~g} \mathrm{~L}^{-1}\right) \%=(\mathrm{Gt} / \mathrm{Gc}) \times 100 \\
\operatorname{GrI} \%=((\mathrm{GrI} 75+\mathrm{GrI} 150) / 2) \times 100
\end{gathered}
$$

where:

$\mathrm{Gt}=$ mean production of plants in treatment;

$\mathrm{Gc}=$ mean production of plants in control.

\subsection{Statistical Analysis}

Analysis of variance (ANOVA) was performed to compare the effect of compost type and its concentration on RSG, RRG, GI and GrI; post-hoc Tukey's test was used. The normality of data distribution and assumption of equal variance were checked using the Shapiro-Wilk and Levene test, respectively. The effect of the chemical properties of the compost extracts within the concentrations was evaluated by correlation analyses. Statistical analysis was performed using SPSS software (IBM SPSS Statistics for Windows, Version 21.0, IBM Corp, Armonk, NY, USA).

\section{Results and Discussion}

\subsection{Relative Seed Germination}

Composts and concentrations analysed in this study did not affect seed germination and the germination percentages were higher $(p<0.05)$ than those found in the control (deionised water).

The ANOVA highlighted that neither compost type nor concentration affected ( $p>0.05)$ RSG after $24 \mathrm{~h}$ (RSG-24), $48 \mathrm{~h}$ (RSG-48) and $72 \mathrm{~h}$ (RSG-72). 
Furthermore, no differences ( $p>0.05$ ) were found between RSG obtained at 24,48 and $72 \mathrm{~h}$. The mean values of RSG obtained were 95.6, 95.0 and $96.4 \%$ after 24 h, $48 \mathrm{~h}$ and $72 \mathrm{~h}$, respectively (Figure 2).
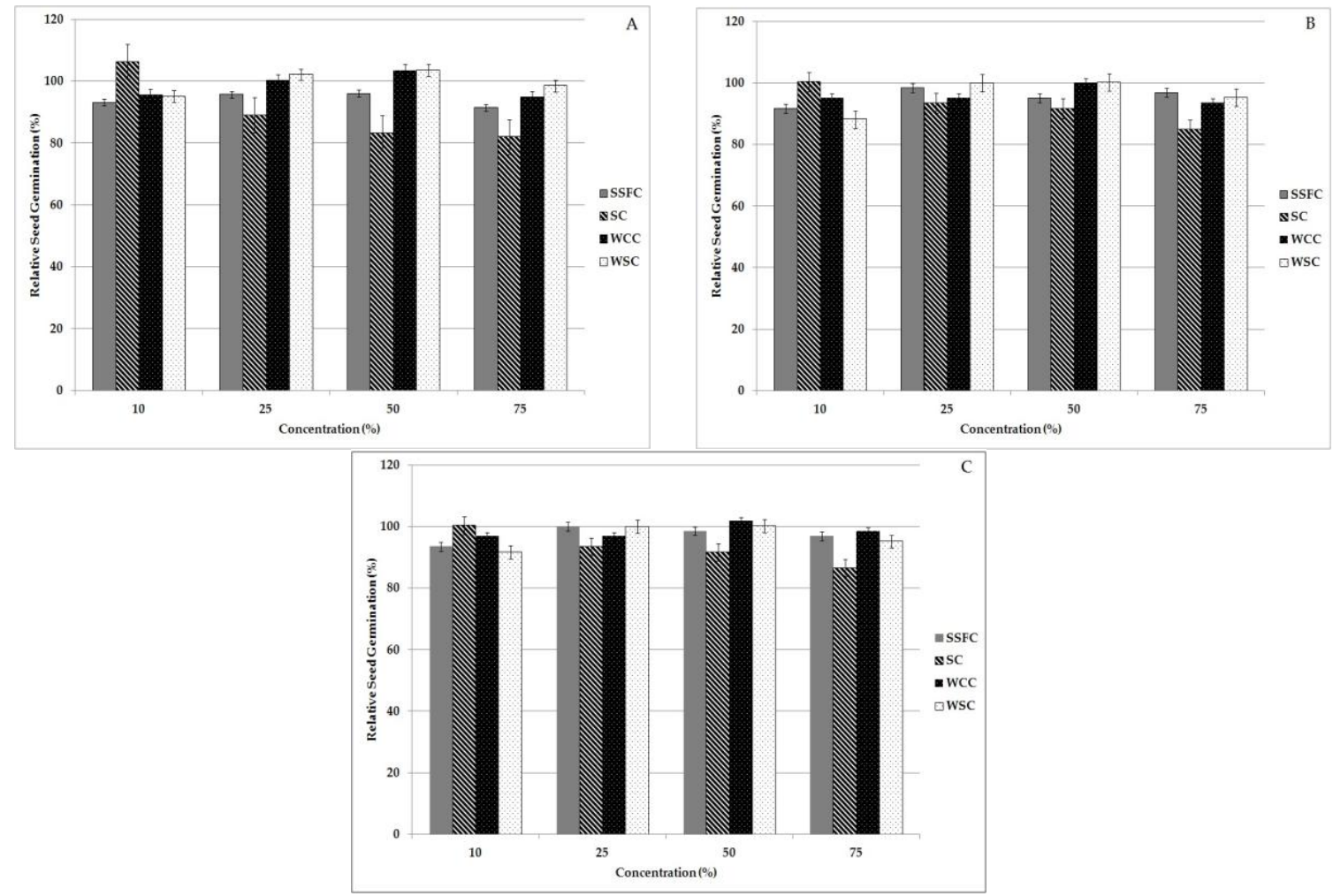

Figure 2. RSG of cress seeds in water extract of four compost (WSC: wheat straw compost; WCC: woodchips compost; SC: sawdust compost; SSFC: slurry solid fraction compost) in four concentrations after $24 \mathrm{~h}(\mathbf{A}) ; 48 \mathrm{~h}(\mathbf{B})$ and $72 \mathrm{~h}(\mathbf{C})$. Error bars indicate standard error $(n=6)$.

\subsection{Relative Root Growth and Germination Index}

Table 3 shows the results of relative root growth (RSG). The rank of mean RRG for the compost extracts was SSFC > SC > WCC > WSC. At all concentrations, RRG of all composts exceeded $100 \%$, suggesting a stimulating effect on root growth (Table 3). At the 10\% concentration, the RRG of SSFC was higher $(p<0.05)$ than WSC and WCC. At the $25 \%, 50 \%$ and $75 \%$ concentrations, the RRG values were not different $(p>0.05)$.

Table 3. RRG of cress seeds as affected by water extracts of four compost (WSC: wheat straw compost, WCC: woodchip compost, SC: sawdust compost, SSFC: slurry solid fraction compost) in four concentrations after $72 \mathrm{~h}$. Data are the mean of six replicates.

\begin{tabular}{cccccc}
\hline \multirow{2}{*}{ Compost } & \multicolumn{4}{c}{ Concentration } & \multirow{2}{*}{ Mean } \\
\cline { 2 - 5 } & $\mathbf{7 5 \%}$ & $\mathbf{5 0 \%}$ & $\mathbf{2 5 \%}$ & $\mathbf{1 0 \%}$ & \\
\hline WSC & $185.5^{\mathrm{a}}$ & $199.0^{\mathrm{a}}$ & $157.0^{\mathrm{a}}$ & $119.7^{\mathrm{a}}$ & 165.3 \\
WCC & $231.7^{\mathrm{a}}$ & $212.1^{\mathrm{a}}$ & $197.1^{\mathrm{a}}$ & $120.0^{\mathrm{a}}$ & 190.2 \\
SC & $226.5^{\mathrm{a}}$ & $235.4^{\mathrm{a}}$ & $226.0^{\mathrm{a}}$ & $179.7^{\mathrm{ab}}$ & 216.9 \\
SSFC & $275.8^{\mathrm{a}}$ & $264.0^{\mathrm{a}}$ & $270.1^{\mathrm{a}}$ & $278.3^{\mathrm{b}}$ & 272.1 \\
Mean & $229.9^{\mathrm{a}}$ & $227.6^{\mathrm{a}}$ & 212.6 & 174.4 & \\
\hline
\end{tabular}

RRG mean values followed by the same letter (a or b) within columns are not significantly different $(p>0.05)$. 
Table 4 presents the relationship between the germination index and compost extracts. Growth stimulation was observed at all concentrations of composts extracts. The germination indices were always greater than the control (water only with GI $=100 \%$ ). The increase in GI was due to longer root length when compared with the control. The presence of adequate amounts of $\mathrm{NH}_{4}{ }^{+}$and other nutrients in composts extracts could be the cause of the high GI obtained [26].

Table 4. GI of cress seeds as affected by water extracts of four compost (WSC: wheat straw compost, WCC: woodchip compost, SC: sawdust compost, SSFC: slurry solid fraction compost) in four concentrations after $72 \mathrm{~h}$. Data are the mean of six replicates.

\begin{tabular}{cccccc}
\hline \multirow{2}{*}{ Compost } & \multicolumn{4}{c}{ Concentration } & \multirow{2}{*}{ Mean } \\
\cline { 2 - 5 } & $\mathbf{7 5 \%}$ & $\mathbf{5 0 \%}$ & $\mathbf{2 5 \%}$ & $\mathbf{1 0 \%}$ & \\
\hline WSC & $176.6^{\mathrm{a}}$ & $199.4^{\mathrm{a}}$ & $157.0^{\mathrm{a}}$ & $109.7^{\mathrm{a}}$ & 160.7 \\
WCC & $228.3^{\mathrm{a}}$ & $216.0^{\mathrm{a}}$ & $190.9^{\mathrm{a}}$ & $116.2^{\mathrm{a}}$ & 187.9 \\
SC & $195.9^{\mathrm{a}}$ & $215.8^{\mathrm{a}}$ & $211.4^{\mathrm{a}}$ & $180.4^{\mathrm{ab}}$ & 200.9 \\
SSFC & $267.1^{\mathrm{a}}$ & $260.1^{\mathrm{a}}$ & $270.1^{\mathrm{a}}$ & $260.3^{\mathrm{b}}$ & 264.4 \\
Mean & 217.0 & $222.8^{\mathrm{a}}$ & $207.4^{\mathrm{a}}$ & 166.7 & \\
\hline
\end{tabular}

GI mean values followed by the same letter (a or b) within columns are not significantly different $(p>0.05)$.

As reported by Zucconi et al. [27], the compost is phytotoxin-free when GI values are higher than $80 \%$. The WSC, WCC, SC and SSFC showed GI values higher than this limit and, therefore, they can be considered phytotoxin-free.

\subsection{Plant Growth Bioassay}

Table 5 shows the results of the plant growth bioassay (GrI).

The ANOVA highlighted that compost type affects $(p<0.05)$ GrI. The order in mean GrI for the four composts investigated was SSFC $>$ SC $>$ WCC $>$ WSC (Table 5). For all composts Growth Index was higher $(p<0.05)$ than that found in the control (without compost) suggesting a stimulating effect on plant growth.

Table 5. Growth Index (GrI) values. Data are the mean of six replicates.

\begin{tabular}{cccc}
\hline \multirow{2}{*}{ Compost } & GrI75 & GrI150 & GrI \\
\cline { 2 - 4 } & $\left.\mathbf{( g ~ L}^{-\mathbf{1}}\right)$ & $\left.\mathbf{( g ~ L}^{-1}\right)$ & $\mathbf{( \% )}$ \\
\hline WSC & 85.7 & 157.1 & $121.4^{\mathrm{a}}$ \\
WCC & 166.7 & 219.6 & $193.1^{\mathrm{b}}$ \\
SC & 170.5 & 233.3 & $201.9^{\mathrm{b}}$ \\
SSFC & 189.4 & 269.5 & $229.4^{\mathrm{b}}$ \\
\hline
\end{tabular}

GrI mean values followed by the same letter (a or b) within columns are not significantly different $(p>0.05)$.

According to some authors [25], compost with GrI values greater than $100 \%$ is considered not phytotoxic. All the composts investigated showed GrI values higher than this limit and, therefore, they can be considered phytotoxin-free.

\subsection{Linear Correlations}

As reported in Table 6, ammonium appeared not to affect $(p>0.05)$ seed germination and root growth; these results are in line with those reported by Hoekstra et al. [28]. 
Table 6. Linear correlations (shown by letters) between RSG after $24 \mathrm{~h}$ (RSG-24), RRG and GI at four compost concentrations with five chemical parameters of the compost extracts.

\begin{tabular}{|c|c|c|c|c|c|c|}
\hline Concentration & & $\mathrm{NH}_{4}{ }^{+}$ & Total N & Ext. Zn & Ext. Cu & EC \\
\hline \multirow{3}{*}{$10 \%$} & RSG-24 & $0.21 \mathrm{NS}$ & $0.22 \mathrm{NS}$ & $-0.08 \mathrm{NS}$ & $-0.14 \mathrm{NS}$ & $0.19 \mathrm{NS}$ \\
\hline & RRG & -0.14 NS & $-0.24 \mathrm{NS}$ & $0.52^{\mathrm{A}}$ & $0.63^{\mathrm{A}}$ & $0.34 \mathrm{NS}$ \\
\hline & GI & $-0.06 \mathrm{NS}$ & $-0.16 \mathrm{NS}$ & $0.49^{\mathrm{a}}$ & $0.56^{\mathrm{A}}$ & $0.37 \mathrm{NS}$ \\
\hline \multirow{3}{*}{$25 \%$} & RSG-24 & $-0.21 \mathrm{NS}$ & $-0.19 \mathrm{NS}$ & $-0.05 \mathrm{NS}$ & $-0.01 \mathrm{NS}$ & $-0.29 \mathrm{NS}$ \\
\hline & RRG & $0.03 \mathrm{NS}$ & $-0.04 \mathrm{NS}$ & $0.34 \mathrm{NS}$ & $0.31 \mathrm{NS}$ & $0.20 \mathrm{NS}$ \\
\hline & GI & $-0.01 \mathrm{NS}$ & $-0.08 \mathrm{NS}$ & $0.34 \mathrm{NS}$ & $0.32 \mathrm{NS}$ & $0.16 \mathrm{NS}$ \\
\hline \multirow{3}{*}{$50 \%$} & RSG-24 & $-0.34 \mathrm{NS}$ & $-0.32 \mathrm{NS}$ & $-0.02 \mathrm{NS}$ & $0.04 \mathrm{NS}$ & $-0.46^{\mathrm{a}}$ \\
\hline & RRG & $0.01 \mathrm{NS}$ & $-0.04 \mathrm{NS}$ & $0.20 \mathrm{NS}$ & $0.20 \mathrm{NS}$ & $0.13 \mathrm{NS}$ \\
\hline & GI & $-0.05 \mathrm{NS}$ & $0.09 \mathrm{NS}$ & $0.20 \mathrm{NS}$ & $0.21 \mathrm{NS}$ & $0.05 \mathrm{NS}$ \\
\hline \multirow{3}{*}{$75 \%$} & RSG-24 & $-0.27 \mathrm{NS}$ & $-0.25 \mathrm{NS}$ & $-0.06 \mathrm{NS}$ & $0.02 \mathrm{NS}$ & $-0.43^{\mathrm{a}}$ \\
\hline & RRG & $-0.01 \mathrm{NS}$ & $-0.11 \mathrm{NS}$ & $0.37 \mathrm{NS}$ & $0.32 \mathrm{NS}$ & $0.08 \mathrm{NS}$ \\
\hline & GI & $-0.08 \mathrm{NS}$ & $-0.17 \mathrm{NS}$ & $0.38 \mathrm{NS}$ & $0.34 \mathrm{NS}$ & $0.01 \mathrm{NS}$ \\
\hline
\end{tabular}

Unlike results of other phytotoxicity experiments [29,30], ammonium appeared not to affect seed germination and root growth. However, ammonium in solution can be toxic to plant growth. The toxicity results mainly from ammonia $\left(\mathrm{NH}_{3}\right)$, which affects plant growth and metabolism at low concentration levels at which $\mathrm{NH}_{4}{ }^{+}$is not harmful [31]. The concentration of ammonia depends on the concentration of $\mathrm{NH}_{4}{ }^{+}$via the equilibrium $\mathrm{NH}_{4}{ }^{+}(\mathrm{aq})=\mathrm{NH}_{3}(\mathrm{aq})+\mathrm{H}^{+}$and on the volatilisation of $\mathrm{NH}_{3}$. A concentration of $\mathrm{NH}_{3}$ of $13 \mathrm{mM}$ has been proved to be toxic [32]. However, concentrations of $\mathrm{NH}_{3}$ (as calculated from the $\mathrm{pH}$ and concentration $\mathrm{NH}_{4}{ }^{+}$by means of the equilibrium equation) in the composts extracts of the experiment were below this value.

EC showed a statistically significant negative correlation with RSG-24 at the 50\% and 75\% concentrations (Table 6). Salinity can have a detrimental effect on seed germination and plant growth, especially in the seedling stage, though the response of various plant species to salinity differs considerably. In general, salinity effects are mostly negligible in extracts, with EC readings of $2.50 \mathrm{dS} \mathrm{m}^{-1}$ or less [33]. This critical level was exceeded in the SC and SSFC extracts in the $50 \%$ and $75 \%$ concentrations.

Water-extractable $\mathrm{Cu}$, which was highest in SSFC, appeared to be positively correlated with RRG and GI at the $10 \%$ concentration. However it is known that heavy metals can cause a marked delay in germination, and that they can severely inhibit plant growth. Concentration of water-extractable $\mathrm{Cu}$ in the compost extracts was maximally $0.21 \mu \mathrm{g} \mathrm{mL}^{-1}$, though according to results from a previous study [28], $0.04 \mu \mathrm{g} \mathrm{mL}^{-1}$ of $\mathrm{Cu}$ inhibit root growth of plants. However, it should be mentioned that critical concentrations of heavy metals for toxicity in compost extracts are likely to be higher than critical values mentioned in literature, because of the relatively high amount of organic compounds, which can bind heavy metals [28].

Water-extractable $\mathrm{Zn}$ showed a high and significant positive correlation with RRG and significant but less high correlation with GI at the $10 \%$ concentration (Table 6). Concentration of water-extractable $\mathrm{Zn}$ was below phytotoxic levels as mentioned in the literature. The maximum concentration of water-extractable $\mathrm{Zn}$ in the compost extracts was $1.2 \mathrm{mg} \mathrm{L}^{-1}$ compared to critical values ranging from 75 to $600 \mathrm{mg} \mathrm{L}^{-1}$ as reported by Hoekstra et al. [28]. This might explain the fact that no significant negative correlations of water-extractable Zn with RSG-24, RRG and GI were found.

\section{Conclusions}

Four different composts, resulting from pig slurry SF composting with three vegetal bulking agents, underwent bioassays to evaluate their potential toxicity following cress (Lepidium sativum L.) germination index and root length assessments. 
The mean values of germination index obtained were $160.7 \%, 187.9 \%, 200.9 \%$ and $264.4 \%$ for WSC, WCC, SC and SSFC, respectively. The growth index values of all composts investigated were $>100 \%-121.4 \%, 193.1 \%, 201.9 \%$ and $229.4 \%$ for WSC, WCC, SC and SSFC, respectively-suggesting a stimulating effect on plant growth.

The outcomes of the investigation suggest that compost from pig slurry solid fraction (SSFC) and mixtures of pig slurry solid fraction with different vegetal materials as bulking agents (WSC, WCC, SC) after 130 days of composting, are phytotoxic-free. For this reason, it can be concluded that the four composts could be used for organic pellet production and subsequently distributed as a soil amendment without risk on seed germination and plantlet growth.

Acknowledgments: This work was carried out within the framework of the "FITRAREF" project, funded by the Italian Ministry of Agriculture and Forestry (GRANT NUMBER, DM29638/7818/10).

Author Contributions: Niccolò Pampuro, Carlo Bisaglia, Ester Foppa Pedretti and Eugenio Cavallo conceived and designed the experiments; Niccolò Pampuro performed the experiments; Elio Romano and Massimo Brambilla analyzed the data; Niccolo Pampuro and Eugenio Cavallo wrote the paper.

Conflicts of Interest: The authors declare no conflict of interest. The funding sponsors had no role in the design of the study; in the collection, analyses, or interpretation of data; in the writing of the manuscript, and in the decision to publish the results.

\section{References}

1. ISTAT-Italian National Institute of Statistics (2012). Preliminary Results of the 6th General Census of Agriculture. Available online: http:/ / censimentoagricoltura.istat.it (accessed on 28 March 2016).

2. Kunz, A.; Miele, M.; Steinmetz, R.L.R. Advanced swine manure treatment and utilization in Brazil. Bioresour. Technol. 2009, 100, 5485-5489. [CrossRef] [PubMed]

3. Lu, L.-L.; Wang, X.-D.; Xu, M.-H. Effect of zinc and composting time on dynamics of different soluble copper in chicken manures. Agric. Sci. China 2010, 9, 861-870. [CrossRef]

4. Gomez-Brandon, M.; Lazcano, C.; Dominguez, J. The evaluation of stability and maturity during the composting of cattle manure. Chemosphere 2008, 70, 436-444. [CrossRef] [PubMed]

5. Salazar, F.J.; Chadwick, D.; Pain, B.F.; Hatch, D.; Owen, E. Nitrogen budgets for three cropping systems fertilized with cattle manure. Bioresour. Technol. 2005, 96, 235-245. [CrossRef] [PubMed]

6. Fangueiro, D.; Lopes, C.; Surgy, S.; Vasconcelos, E. Effect of the pig slurry separation techniques on the characteristics and potential availability of $\mathrm{N}$ to plants in the resulting liquid and solid fractions. Biosyst. Eng. 2012, 113, 187-194. [CrossRef]

7. Pampuro, N.; Facello, A.; Cavallo, E. Pressure and specific energy requirements for densification of compost derived from swine solid fraction. Span. J. Agric. Res. 2013, 11, 678-684. [CrossRef]

8. Pampuro, N.; Bagagiolo, G.; Priarone, P.C.; Cavallo, E. Effects of pelletizing pressure and the addition of woody bulking agents on the physical and mechanical properties of pellets made from composted pig solid fraction. Powder Technol. 2017, 311, 112-119. [CrossRef]

9. Romano, E.; Brambilla, M.; Bisaglia, C.; Pampuro, N.; Foppa Pedretti, E.; Cavallo, E. Pelletization of composted swine manure solid fraction with different organic co-formulates: Effect of pellet physical properties on rotating spreader distribution patterns. Int. J. Recycl. Org. Waste Agric. 2014, 3, $101-111$. [CrossRef]

10. Alemi, H.; Kianmehr, M.H.; Borghaee, A.M. Effect of pellet processing of fertilization on slow-release nitrogen in soil. Asian J. Plant Sci. 2010, 9, 74-80.

11. Pampuro, N.; Dinuccio, E.; Balsari, P.; Cavallo, E. Gaseous emissions and nutrient dynamics during composting of swine solid fraction for pellet production. Appl. Math. Sci. 2014, 8, 6459-6468. [CrossRef]

12. Pampuro, N.; Dinuccio, E.; Balsari, P.; Cavallo, E. Evaluation of two composting strategies for making pig slurry solid fraction suitable for pelletizing. Atmos. Pollut. Res. 2016, 7, 288-293. [CrossRef]

13. Nolan, T.; Troy, S.M.; Healy, M.G.; Kwapinski, W.; Leahy, J.J.; Lawlor, P.G. Characterization of compost produced from separated pig manure and a variety of bulking agents at low initial $\mathrm{C} / \mathrm{N}$ ratios. Bioresour. Technol. 2011, 102, 7131-7138. [CrossRef] [PubMed] 
14. Parkinson, R.; Gibbs, P.; Burchett, S.; Misselbrook, T. Effect of turning regime and seasonal weather conditions on nitrogen and phosphorus losses during aerobic composting of cattle manure. Bioresour. Technol. 2004, 91, 171-178. [CrossRef]

15. Bernal, M.P.; Alburquerque, J.A.; Moral, R. Composting of animal manures and chemical criteria for compost maturity assessment. A review. Bioresour. Technol. 2009, 100, 5444-5453. [CrossRef] [PubMed]

16. Chrysargyris, A.; Saridakis, C.; Tzortzakis, N. Use of municipal solid waste compost as growing medium component for melon seedlings production. J. Plant Biol. Soil Health 2013, 2, 1-5.

17. Papamichalaki, M.; Papadaki, A.; Tzortzakis, N. Substitution of peat with municipal solid waste compost in watermelon seedling production combined with fertigation. Chil. J. Agric. Res. 2014, 74, 452-459. [CrossRef]

18. He, M.-M.; Tian, G.-M.; Liang, X.-Q. Phytotoxicity and speciation of copper, zinc and lead during the aerobic composting of sewage sludge. J. Hazad. Mater. 2009, 163, 671-677. [CrossRef] [PubMed]

19. Liu, S.; Wang, X.-D.; Lu, L.-L.; Diao, S.-R.; Zhang, J.-F. Competitive complexation of copper and zinc by sequentially extracted humic substances from manure compost. Agric. Sci. China 2008, 7, 1253-1259. [CrossRef]

20. Tam, N.F.Y.; Tiquia, S. Assessing toxicity of spent pig litter using a seed germination technique. Resour. Conserv. Recy 1994, 11, 261-274. [CrossRef]

21. Caceres, F.; Flotats, X.; Marfa, O. Changes in the chemical and physiochemical properties of the solid fraction of cattle slurry during composting using different aeration strategies. Waste Manag. 2006, 26, 1081-1091. [CrossRef] [PubMed]

22. Page, A.L.; Miller, R.H.; Keeney, D.R. Methods of Soil Analysis; Part 2; American Society of Agronomy, Inc. Soil Science of America: Madison, WI, USA, 1982.

23. Piemonte, R. Metodi di analisi dei compost. Collana Ambient. 1998, 6, 84-87.

24. Fuentes, A.; Llorens, M.; Saez, J.; Aguilar, M.I.; Ortuno, J.F.; Meseguer, V.F. Phytotoxicity and heavy metals speciation of stabilised sewage sludges. J. Hazad. Mater. 2004, 108, 161-169. [CrossRef] [PubMed]

25. Piemonte, R. Il compostaggio: Processo, tecniche ed applicazione. Collana Ambient. 2001, 25, 83-88.

26. Romero, C.; Ramos, P.; Costa, C.; Marquez, M.C. Raw and digested municipal waste compost leachate as potential fertilizer: Comparison with a commercial fertilizer. J. Clean. Prod. 2013, 59, 73-78. [CrossRef]

27. Zucconi, F.; Pera, A.; Forte, M.; De Bertoldi, M. Evaluating toxicity of immature compost. BioCycle 1981, 22, $54-57$.

28. Hoekstra, N.J.; Bosker, T.; Lantinga, E.A. Effects of cattle dung from farms with different feeding strategies on germination and initial root growth of cress (Lepidium sativum L.). Agric. Ecosyst. Environ. 2002, 93, 189-196. [CrossRef]

29. Tiquia, S.M.; Tam, N.F.Y. Elimination of phytotoxicity during co-composting of spent pig-manure sawdust litter and pig sludge. Bioresour. Technol. 1998, 65, 43-49. [CrossRef]

30. Wong, M.H.; Cheung, Y.H.; Cheung, C.L. The effects of ammonia and ethylene oxide in animal manure and sewage sludge on the seed germination and root elongation of Brassica parachinensis. Environ. Pollut. 1983, 30, 109-123. [CrossRef]

31. Mengel, K.; Kirkby, E.A. Principles of Plant Nutrition, 4th ed.; International Potash Insitute: Horgen, Switzerland, 1987; p. 745.

32. Bennet, A.C.; Adams, F. Concentration of $\mathrm{NH}_{3}$ (aq) required for incipient $\mathrm{NH}_{3}$ toxicity to seedlings. Soil Sci. Soc. Am. J. 1970, 34, 259-263. [CrossRef]

33. Ofosu-Budu, G.K.; JHogarh, J.N.; Fobil, J.N.; Quaye, A.; Danso, S.K.A.; Carboo, D. Harmonizing procedures for the evaluation of compost maturity in two compost types in Ghana. Resour. Conserv. Recycl. 2010, 54, 205-209. [CrossRef]

(C) 2017 by the authors. Licensee MDPI, Basel, Switzerland. This article is an open access article distributed under the terms and conditions of the Creative Commons Attribution (CC BY) license (http:/ / creativecommons.org/licenses/by/4.0/). 